\title{
Molecular Cytogenetic Analysis in Freshwater Prawns of the Genus Macrobrachium (Crustacea: Decapoda: Palaemonidae)
}

\author{
Wagner F. Molina $\left.{ }^{1}{ }^{(}\right)$, Gideão W. W. F. Costa ${ }^{1}$, Inailson M. C. Cunha ${ }^{1}$, Luiz A. C. Bertollo ${ }^{2}$, \\ Tariq Ezaz $^{3}$ (D), Thomas Liehr ${ }^{4, *(D)}$ and Marcelo B. Cioffi ${ }^{2}$ (D) \\ 1 Departamento de Biologia Celular e Genética, Centro de Biociências, Universidade Federal do Rio Grande \\ do Norte, Natal, RN 59078970, Brazil; molinawf@yahoo.com.br (W.F.M.); \\ wagnerwf@yahoo.com.br (G.W.W.F.C.); inailsonmarcio@gmail.com (I.M.C.C.) \\ 2 Laboratório de Citogenética de Peixes, Departamento de Genética e Evolução, Universidade Federal de São \\ Carlos, São Carlos, SP C.P. 676, Brazil; bertollo@ufscar.br (L.A.C.B.); mbcioffi@ufscar.br (M.B.C.) \\ 3 Institute for Applied Ecology, University of Canberra, Canberra, ACT 2617, Australia; \\ Tariq.Ezaz@canberra.edu.au \\ 4 Institute of Human Genetics, University Hospital Jena, 7747 Jena, Germany \\ * Correspondence: Thomas.Liehr@med.uni-jena.de
}

Received: 21 March 2020; Accepted: 7 April 2020; Published: 9 April 2020

\begin{abstract}
Freshwater prawns of the genus Macrobrachium are one of the important components of circumtropical marine, estuarine, and freshwater environments. They have been extensively exploited for human consumption for many years. More than 250 species reflect the evolutionary success of this highly diversified group, with a complex and challenging taxonomy due to morphological variations and vast geographical distribution. Although genetic approaches have been used to clarify phylogenetic and taxonomic aspects of Macrobrachium species, cytogenetic information is still very scarce and mostly focused on chromosome number and morphology. Here, we present chromosome data for three species from the Neotropical region, M. carcinus, M. acanthurus, and $M$. amazonicum, and one species from the Oriental region, $M$. rosenbergii. Using conventional cytogenetic approaches and chromosome mapping of repetitive DNAs by fluorescence in situ hybridization (FISH), we identified numerical diversification of the diploid set, within and between both zoogeographic regions. These included M. acanthurus and M. amazonicum sharing diploid chromosomes of 98, while $M$. carcinus has 94 , and M. rosenbergii has 118 chromosomes. Argentophilic sites are also variable in number, but they occur in a much higher number than $18 \mathrm{~S}$ rDNA, representing two to 10 sites within the study species. Microsatellites repeat motifs are also abundant in the chromosomes, with a co-localization and uniform distribution along the chromosome arms, but completely absent in the AT-rich centromeric regions. As a whole, our study suggests that the $2 \mathrm{n}$ divergence was followed by a considerable rDNA diversification. The abundance of the exceptional amount of microsatellite sequences in the chromosomes also suggests that they are essential components of the Macrobrachium genome and, therefore, maintained as a shared feature by the species, the reason for which is yet unknown.
\end{abstract}

Keywords: crustacea cytogenetics; karyotype evolution; rDNA; SSRs; diploid variation

\section{Introduction}

Palaemonidae (Decapoda) is a diverse family of shrimp having considerable economic interest [1], comprising 137 genera and more than 950 species distributed in marine, estuarine, and freshwater environments around the world [2]. In this family, the genus Macrobrachium Spence Bate, 1868, 
constitutes a very diversified group comprising more than 250 species [3], and important links in trophic chains of lakes, rivers, and estuarine areas of tropical and subtropical regions $[4,5]$. The species of this genus are characterized by a second pair of very elongated locomotory appendices, generally equal to or larger than the body size, with prominent chelae [6].

This genus was probably originated during the later Cretaceous, in the Sea of Tethys, whose fragmentation promoted its disjunct distribution and consequent isolation of the American and African strains that are relics of this period [7]. The greatest diversity of species occurs in the Indo-Pacific region, including India and Southeast Asia, parts of Oceania and some Pacific islands, whereas other lineages are found along the west African coast [8], and in Americas, from the south of the USA to the south of Brazil [9-11].

Macrobrachium species are important resources in aquaculture and fisheries in many countries [12]. Among them, the giant river prawn, M. rosenbergii, has been the focus of scientific and economic attentions due to its intensive use in aquaculture worldwide [13]. Therefore, some karyotype and genome data are already available for this species [14-17]. However, native species from different countries have also been increasingly used for aquaculture purposes [18]. In turn, from the biological conservation view, $M$. rosenbergii represents a serious risk to ecosystems of many countries where it is invasive [19], including Brazilian regions comprising a large number of congeneric species [20-22].

The real diversity of Macrobrachium is still largely unknown, with continuous taxonomic reviews and descriptions of new species [23-26]. The extensive geographic distributions of some species, associated with highly variable morphological characters $[27,28]$, have driven the integrated use of molecular and morphological data to elucidate their challenging taxonomy (e.g., [29,30]).

Although unexpected given its notable diversity ( $>8000$ species) and economic importance, cytogenetic data are scarce in Decapoda, particularly among Macrobrachium species [31,32]. Low mitotic indices, high 2 n numbers, small chromosomes, and technical limitations [33,34] are possible reasons for the restricted data on karyotype evolution in this group. Only a few dozen species of Decapoda have some cytogenetic information and, when available, mainly related to the diploid number or karyotype structure, with very few reports on molecular cytogenetics or chromosome banding [31,32]. This is also true for Macrobrachium genus, whose cytogenetic data encompass less than $5 \%$ of its diversity (Table 1 ).

Table 1. Cytogenetic data for the family Palaemonidae (Decapoda).

\begin{tabular}{cccc}
\hline Species & 2n & Karyotype & References \\
\hline Macrobrachium & 124 & $22 \mathrm{~m}+22 \mathrm{sm}+80 \mathrm{t} / \mathrm{st}$ & {$[34]$} \\
villosimanus & & $52 \mathrm{~m}+54 \mathrm{sm}+12 \mathrm{st} / \mathrm{t}$ & {$[14]$} \\
M rosenbergii & 118 & $90 \mathrm{~m} / \mathrm{sm}+28 \mathrm{st} / \mathrm{t}$ & {$[15]$} \\
M. rosenbergii & 118 & $118 \mathrm{~m} / \mathrm{sm} / \mathrm{st}$ & Present study \\
M. rosenbergii & 118 & $8 \mathrm{~m}+110 \mathrm{t}$ & {$[35]$} \\
M. lamarrei & 118 & $54 \mathrm{~m}+46 \mathrm{sm}+10 \mathrm{a}+6 \mathrm{t}$ & {$[32]$} \\
M. lanchesteri & 116 & $74 \mathrm{~m}+22 \mathrm{t}+8 \mathrm{st}$ & {$[36]$} \\
M. nipponense & 104 & $50 \mathrm{~m}+24 \mathrm{t}+30 \mathrm{a}$ & {$[37]$} \\
M. idella & 104 & $22 \mathrm{~m}+10 \mathrm{t}+22 \mathrm{a}+\mathrm{XY}$ & {$[37]$} \\
M. scabriculum & 104 & $100 \mathrm{~m}$ & {$[38]$} \\
M. siwalikensis & 100 & $60 \mathrm{~m}+12 \mathrm{sm}+28 \mathrm{t} / \mathrm{st}$ & {$[39]$} \\
M. superbum & 100 & $98 \mathrm{~m} / \mathrm{sm} / \mathrm{st}$ & Present study \\
M. amazonicum & 98 & $98 \mathrm{~m} / \mathrm{sm} / \mathrm{st}$ & Present study \\
M. acanthurus & 98 & $94 \mathrm{~m} / \mathrm{sm} / \mathrm{st}$ & Present study \\
M. carcinus & 94 & $52 \mathrm{~m}+14 \mathrm{sm}+24 \mathrm{st}+6 \mathrm{t}$ & {$[1]$} \\
Palaemon khori & 96 & $56 \mathrm{~m}+8 \mathrm{sm}+12 \mathrm{st}+14 \mathrm{t}$ & {$[40]$} \\
P. modestus & 90 & $40 / \mathrm{mm}+6 / 4 \mathrm{a}\left(\mathrm{X}_{1} \mathrm{X}_{2} \mathrm{Y}\right)$ & {$[41]$} \\
P. elegans & $90 / 89$ & $84 / 85 \mathrm{~m} / \mathrm{sm}+40 \mathrm{t}$ & {$[31]$} \\
P. serratus & 56 & $4 \mathrm{~m}+12 \mathrm{~s}$ & \\
\hline
\end{tabular}

Where $\mathrm{m}$, metacentric; sm, submetacentric; st, subtelocentric; $\mathrm{t}$, telocentric; and a, acrocentric chromosomes. 
At least 55 Macrobrachium species are found in American regions, 17 of which inhabit Brazilian waters [30]. Therefore, accessing their cytogenetic data can provide important clues to understand evolutionary processes in the genus. The objective of present study is to use conventional cytogenetic approaches, as well as FISH mapping of rDNA and repetitive sequences to characterize chromosome organization and compare karyotype characteristics across four Macrobrachium species, three from Brazil (Macrobrachium acanthurus, M. amazonicum, $M$ carcinus) and $M$. rosenbergii to infer karyotype evolution within this group.

\section{Results}

The four Macrobrachium species studied all possess small metacentric (m), submetacentric (sm), and subtelocentric (st) chromosomes, with the smallest pairs presenting $<1.0 \mu \mathrm{m}$ in size. The species of the Neotropical region have smaller diploid numbers in comparison with that from the Oriental region. Thus, $M$. carcinus possesses $2 \mathrm{n}=94$, and $M$. acanthurus and $M$. amazonicum $2 \mathrm{n}=98$, whereas $M$. rosenbergii has $2 \mathrm{n}=118$ chromosomes, which is consistent with previous descriptions for these species $[14,15,42]$. No evidence for male chromosomal heteromorphism was detected at the level of the present investigation (Figure 1).

Large $\mathrm{DAPI}^{+}$centromeric heterochromatic blocks are present in all four species, which are amplified and reach the pericentromeric region in some chromosome pairs. $\mathrm{Ag}^{+}$signals are generally present on the short arms of the chromosomes and, to a lesser extent, in the pericentromeric position, but with intra- and interindividual variation in number (Figure 1).

FISH mapping of the 18S rDNA revealed different numbers of sites for this repetitive family, comprising eight sites in M. amazonicum, 10 in M. acanthurus, two in $M$. carcinus, and four sites in M. rosenbergii. In each species, the $18 \mathrm{~S}$ rDNA sites occupy the terminal regions of chromosome pairs (Figure 1I-L). Noticeably in M. carcinus these sites were larger than in the other species. No specific correlation between the $\mathrm{Ag}^{+}$and the 18S-5.8S-28S rDNA loci was observed, the former being much more frequent in the karyotype (Figure 1E-L).

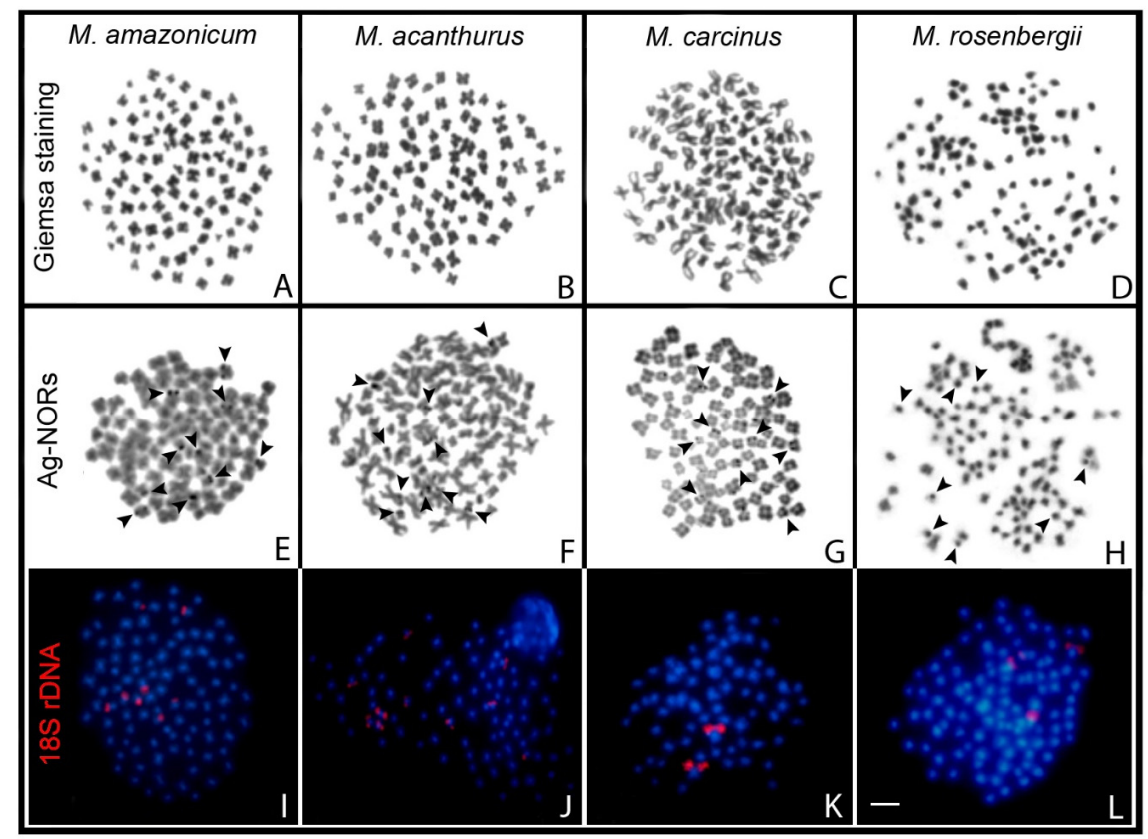

Figure 1. Spermatogonial metaphases of Macrobrachium amazonicus (A,E,I), M. acanthurus (B,F,J), $M$, carcinus $(\mathbf{C}, \mathbf{G}, \mathbf{K})$, and $M$. rosenbergii $(\mathbf{D}, \mathbf{H}, \mathbf{L})$ after Giemsa staining $(\mathbf{A}-\mathbf{D})$; Ag-NOR impregnation (E-H) and FISH with $18 \mathrm{~S}$ rDNA (red) probe (I-L). Blue fluorescence represents chromosomes stained with DAPI and dark arrowheads highlight $\mathrm{Ag}^{+}$signals in the chromosomes. Bar $=5 \mu \mathrm{m}$. 
The mapping of the simple sequence repeats (SSRs) $\left((\mathrm{CA})_{15},(\mathrm{GA})_{15},(\mathrm{CAA})_{10}\right.$, and $\left.(\mathrm{CGG})_{10}\right)$ showed a surprisingly large amount of accumulation/amplification distributed homogeneously along the chromosome arms. However, these sequences are absent in the centromeric regions, where large AT-rich heterochromatic blocks (DAPI ${ }^{+}$) occur (Figure 2). No hybridization signal with the (TTAGGG)n probe was found in any species.

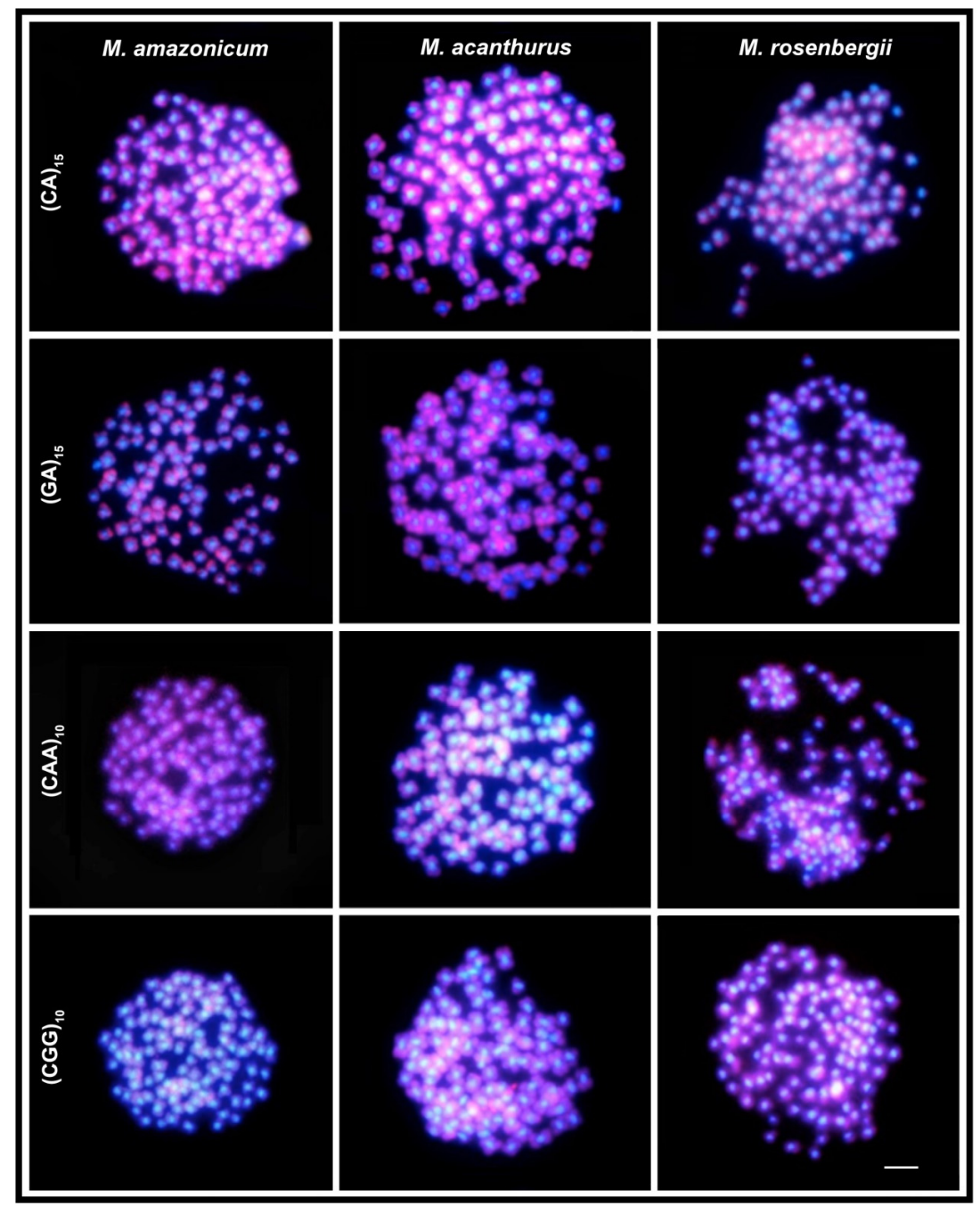

Figure 2. Fluorescence in situ hybridization with microsatellite probes (red fluorescence) in spermatogonial metaphases of Macrobrachium species. Blue fluorescence represents chromosomes stained with DAPI. Bar $=5 \mu \mathrm{m}$.

\section{Discussion}

Decapoda display some of the largest diploid chromosome numbers among animals, with variations ranging from around 50 to hundreds of chromosomes, as in the crab Liocarcinus vernalis, $2 n=54$ [43] and the hermit crab Pagurus ochotensis, $2 n=254$ [44,45]. Such variability is also found in the four species we have now investigated $(2 \mathrm{n}=94-118)$, and, including the published karyotype information, the diploid range for these species is now ( $2 n=94-124)$ (Table 1$)$. According to [41], higher $2 \mathrm{n}$ values constitute an evolutionarily ancestral condition for Decapoda species, thus indicating a karyotype evolution mediated by a variety of chromosome rearrangements, with the Robertsonian translocation playing a prominent role.

The variability of the chromosome numbers contrasts with what occurs in other Decapoda representatives, which exhibit a marked uniformity in their chromosomal numbers. In fact, some marine 
groups such as Penaeidae, with great dispersive potential [46,47], have more stable $2 \mathrm{n}$ numbers (e.g., [48,49]). In contrast, Macrobrachium (Palaemonidae), whose representatives are restricted to freshwater environments, or with dependence on saline environments and with reduced gene flow [50,51], presents a marked diversification. In this respect, ecological aspects deserve to be better understood concerning their probable role in karyotype diversification or stasis (sensu [52]).

Historical biogeography indicates that Macrobrachium species composition results not only from local divergences [53], but also includes long-distance dispersal of different phylogenetic lineages [54]. From a biogeographic context, Macrobrachium possesses contrasting patterns of chromosome numbers, with the American species showing comparatively lower $2 n$ numbers (94-98) and the major Asian species with $2 \mathrm{n}=100-118$ (Table 1; Figure 3). The causes of this divergence are not known, although it is congruent with the exclusivity of clades between both continents. Interestingly, M. carcinus (from the Americas) has $2 \mathrm{n}=94$ and $M$. rosenbergii (from Asia) has $2 \mathrm{n}=118$. Although belonging to the same clade [55], their chromosomal numbers are linked with the karyotype trends in each biogeographic region rather than their common phylogenetic position. Noteworthily, this case highlights independent evolutionary conditions for phylogenetically close species. It is expected that the increase of cytogenetic research will allow us to better understand such differential numerical patterns of karyotypes between the American and Asian biogeographic regions.

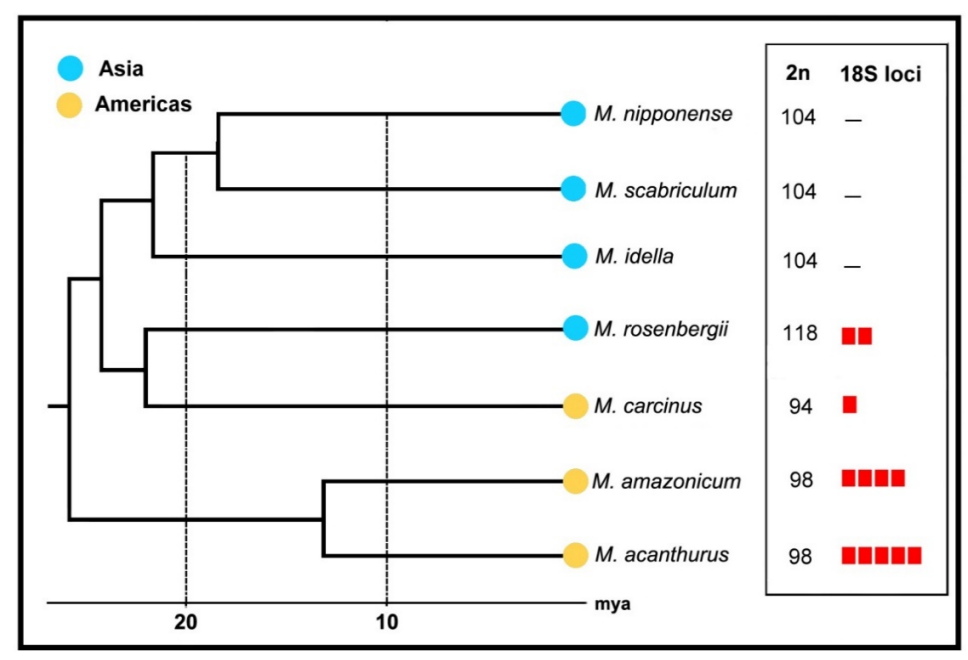

Figure 3. Diploid numbers and frequency of 18S-5.8S-28S rDNA loci in Macrobrachium species from a biogeographic and phylogenetic perspective. The red squares represent the number of chromosome pairs bearing these sequences (adapted from [55]).

Repetitive DNAs are very informative sequences about karyotype evolution and, among them, the 18S-5.8S-28S rRNA genes stand out as one of the most studied ones in the eukaryote genome [56]. The Ag-NOR staining procedure allows us to identify the 18S-5.8S-28S rRNA genes that were transcriptionally active during the previous interphase [57]. However, in Macrobrachium species, a very large number of $\mathrm{Ag}^{+}$signals were found, which far exceed the number of $18 \mathrm{~S}$ rDNA sites unveiled by FISH procedures. It is likely that this characteristic may be related to the argentophilic properties of centromeric proteins [58,59], or pseudo-NORs [60]. Pseudo-NORs are tandem sequences of heterologous DNA sequence with high affinity for a DNA binding protein (upstream binding factor), part of the Pol I transcription machinery that binds across the rDNA repeats [61]. These regions mimic active NORs in a number of important respects, among them the presence of acidic residues, with strong affinity by silver, that could provide additional Ag+ sites without relation with NORs.

In giant freshwater prawns, the $18 \mathrm{~S}$ rDNA was proved to be a discriminating cytotaxonomic character, with a marked phylogenetic link. Accordingly, the number of loci is particular for each one of the analyzed species, with similarities for those phylogenetically close ones (Figure 3). While M. acanthurus and M. amazonicum have higher numbers of $18 \mathrm{~S}$ rDNA sites (10 and eight, 
respectively), their significantly lower numbers are found in $M$. carcinus, $M$. lanchesteri [32], and $M$. rosenbergii (two, four, and four sites, respectively). The occurrence of more than one $18 \mathrm{~S}$ rDNA sites has been reported in several Decapoda groups [31,59,62], suggesting that it may represent an ancestral condition for the order. If so, the single chromosome pair bearing $18 \mathrm{~S}$ rDNA sequences in M. carcinus would indicate a reorganization of this repetitive family of sequences in the karyotype of this species.

Telomeres are highly repeated DNA sequences that protect the ends of the chromosomes [63] and show striking similarity even in evolutionarily distant organisms [64]. In several crustacean groups discernible telomeric signals have been reached using as (TTAGGG)n as (TTAGG)n probes $[65,66]$. However, in Macrobrachium species the FISH experiments with (TTAGGG)n probes did not produce detectable signals. Therefore, further investigations are needed to improve the hybridization method and understand the role of telomeric sequences in the karyotype evolution of Macrobrachium. Another striking characteristic in Macrobrachium species is their large content of AT-rich segments in the centromeric regions. However, this pattern has a broader phylogenetic extension, including other species of the genus [34], other Palaemonidae genera [31], and Decapoda families [66], thus indicating a stable condition for the order.

The variation of DNA content is also remarkable in Palaemonidae, comprising $5.0 \times$ at the family level, and 3.4× particularly among Macrobrachium species. The causes of this variation are not entirely understood in crustaceans [67]; however, the participation of retrotransposons has been identified as one of the main factors in the expansion of the genome in the family [68] and deserves to be clarified using more extensive cytogenetic and genomic approaches. Repetitive sequences, including transposable elements (TE) and microsatellite DNAs, occupy a considerable portion of some Crustacean genomes [69]. TEs contribute to genome expansion and alteration not only by transposition but also by generating tandem repeats [70]. Associations among transposable elements and microsatellite expansions can play an important role in chromosome differentiation [71]. In this sense, estimative of the microsatellites content and organization in the Macrobrachium chromosomes open perspectives for future investigations about the evolutionary interrelationships of these repetitive DNA classes. In Macrobrachium species the mapping of four microsatellite classes revealed their striking content in the genome of species. Significantly, these SSRs overlap all chromosome arms but are absent in the centromeric AT-rich regions. This compartmentalized organization indicates that repetitive DNAs follow divergent and complex evolutionary paths in Macrobrachium species, besides appearing to be integrated with transcriptional regions of the genome.

Increasing invasions of Macrobrachium species occur worldwide as a result of their use in aquaculture [19]. Such events promote contact among geographically isolated species, raising several ecological and evolutionary questions. In South America, for example, the Asian M. rosenbergii has established invasive populations in areas where the native M. amazonicum occurs [21], a condition that also occurs in many other countries [22]. Therefore, it is increasingly necessary to evaluate the potential for intercrossing of Macrobrachium species, as a valuable parameter for biological conservation in the light of genetic introgression risks. Several pieces of evidence have highlighted the substantial interference of the hybridization on evolutionary processes [72,73]. However, its occurrence and effects are yet to be fully known for the freshwater giant prawns.

Remarkably, hybridization experiments among phylogenetically close species from the same biogeographic region have resulted in viable Macrobrachium hybrids [74-77]. In contrast, induced crosses among phylogenetically closer species, but from distant biogeographic regions, produce zygotes which did not go beyond the gastrula stage, i.e., 4-6 days after fertilization [78]. Thus, in Macrobrachium, as in other organisms [79-81], post-zygotic reproductive barriers may result in unequal chromosomal segregations from crosses of individuals bearing different $2 \mathrm{n}$ numbers. Post-zygotic barriers probably related to differences in the chromosome number and distinct biogeographic areas have been reported in experimental crosses among several Macrobrachium species [82-84]. Thus, it is likely that the diversification of the diploid number and structural features reduce the success of hybridizations 
among natural and invasive species from different biogeographic regions. This condition is consistent with the long period of divergence that such lineages have experienced.

\section{Final Remarks}

Conventional and molecular cytogenetic data are useful in estimating evolutionary patterns, as well as probable crossbreeding chances among Macrobrachium species. Apomorphic cytogenetic characteristics ( $2 n$ numbers, karyotype formulas, and frequency and distribution of rDNA), in addition to other shared features (e.g., prevalence of two-armed chromosomes, organization and composition of specific heterochromatin), interact in the evolutionary process of this prawn group. Noteworthy, despite long periods of isolation in different biogeographic regions, some chromosomal characteristics remain conserved, suggesting that they play important roles in the evolutionary history of the genus. In this context, it stands out the striking amount and particular distribution of microsatellite sequences in the in nuclear genomes of analyzed species. Faced with a growing number of biological invasions, hybridization risks among Macrobrachium species are real and viable hybrids have been reported, with serious implications for worldwide aquatic ecosystems. Fortunately, divergences in the number of chromosomes allow us to estimate effective post-zygotic barriers. In this sense, investigations of such simple and useful cytogenetic indicators deserve to be increased given their important contribution towards genetic conservation.

\section{Materials and Methods}

\subsection{Species Analyzed}

Macrobrachium males of three South American species, M. carcinus (Linnaeus, 1758), M. acanthurus (Wiegmann, 1836), and M. amazonicum (Heller, 1862), and one Asian species, M. rosenbergii (de Man, 1879) were analyzed. Natural samples of $M$. carcinus and $M$. acanthurus were from Jiqui Lake $\left(5^{\circ} 55^{\prime} 07.7^{\prime \prime}\right.$ $\left.\mathrm{S} / 35^{\circ} 11^{\prime} 17.6^{\prime \prime} \mathrm{W}\right)$, municipality of Parnamirim. M. amazonicum was from an invasive population in the Seridó River $\left(6^{\circ} 27^{\prime} 14.9^{\prime \prime} \mathrm{S} / 37^{\circ} 06^{\prime} 25.6^{\prime \prime} \mathrm{W}\right)$, municipality of Caicó. Both locations are situated in the Rio Grande do Norte State, northeastern Brazil. Individuals of $M$. rosenbergii were obtained from a freshwater prawn farm in the Paraíba State, also in NE Brazil.

\subsection{Chromosome Preparations}

Chromosomes were obtained from male gonads using the method described by Klingerman and Bloom [85], with modifications suggested by Lakra et al. [42]. The specimens received an injection of colchicine solution $(2.0 \mu \mathrm{g} / \mathrm{g}$ of body weight) at the base of the third pair of pereiopods and were kept in constantly aerated aquariums for $6 \mathrm{~h}$. The testicles were removed, sectioned into 1-mm pieces, and subjected to a $0.075 \mathrm{M} \mathrm{KCl}$ hypotonic solution for $40 \mathrm{~min}$. After that, the fragments were fixed in a methanol plus acetic acid (3:1) solution, three changes $15 \mathrm{~min}$ each, and stored at $-20{ }^{\circ} \mathrm{C}$. Spermatogonial metaphases were obtained by macerating the tissues in $1.0 \mathrm{~mL}$ of $50 \%$ acetic acid solution with tweezers. About $150 \mu \mathrm{L}$ of the cell suspension was dropped and immediately re-aspirated with a Pasteur pipette on heated slides at $55{ }^{\circ} \mathrm{C}$ and air-dried. Chromosomes were stained with $10 \%$ Giemsa solution diluted in phosphate buffer (pH 6.8), and analyzed under an optical microscope at $1200 \times$ magnification. Chromosomes were classified as metacentric $(\mathrm{m})$, submetacentric (sm), subtelocentric (st), or acrocentric (a), according to their centromere positions [86].

The detection of the nucleolus organizing regions (Ag-NORs) was performed using the Silver nitrate staining procedure [87]. For fluorochrome staining, the slides were mounted with $30 \mu \mathrm{L}$ of Vectashield anti-fading medium (Vector Laboratories, Burlingame, CA, USA) plus $1.0 \mu \mathrm{L} / \mathrm{mL}$ of DAPI, covered with coverslips and kept at $4{ }^{\circ} \mathrm{C}$ in the dark. The analyses were carried out using an Olympus ${ }^{\mathrm{TM}}$ BX51 epifluorescence photomicroscope with appropriate filters. The best results were photographed using the Olympus DP73 digital capture system with cellSens 1.7 (Olympus Soft Imaging Solutions, Münster, Germany). 
The experimental work fulfills all ethical guidelines regarding the handling of specimens. The collection and handling of specimens followed protocols approved by the Ethics Committee on the Use of Animals of the Federal University of Rio Grande do Norte (\#044/2015).

\subsection{Fluorescence In Situ Hybridization (FISH)}

The $18 \mathrm{~S}$ rDNA probes (1200 bp) were obtained by a polymerase chain reaction, from the nuclear DNA of Macrobrachium carcinus (Crustacea, Palaemonidae) using the NS1 5'-GTA GTC ATA TGC TTG TCT C-3' and NS8 5'-TCC GCA GGT TCA CCT ACG GA-3' primers [88]. Subsequently, the probe was labeled by nick translation with digoxigenin-11-dUTP (Roche, Mannheim, Germany). FISH experiments were performed according to [89]. Slides with chromosome preparations were washed with $1 \times$ PBS buffer for $5 \mathrm{~min}$ at $25^{\circ} \mathrm{C}$ and subsequently dehydrated in an alcoholic series (70\%/80\%/100\%). Next, the chromosomes were treated with DNAse-free RNAse ( $20 \mathrm{mg} / \mathrm{mL}$ in $2 \times \mathrm{SSC}$ ) at $37^{\circ} \mathrm{C}$ for $1 \mathrm{~h}$, with pepsin $(0.005 \%$ in $10 \mathrm{mM} \mathrm{HCl})$ at $37^{\circ} \mathrm{C}$ for $10 \mathrm{~min}$, fixed with $1 \%$ formaldehyde for $10 \mathrm{~min}$, and then dehydrated in an alcoholic series. The chromosomes were then denatured in $70 \%$ formamide $/ 2 \times \mathrm{SSC}$ at $72{ }^{\circ} \mathrm{C}$ for $5 \mathrm{~min}$. A hybridization solution comprising $50 \%$ formamide, $2 \times \mathrm{SSC}$, $10 \%$ dextran sulfate, and the denatured probe $(5 \mathrm{ng} / \mu \mathrm{L})$ was applied on the slides overnight at $37^{\circ} \mathrm{C}$. After hybridization, the slides were washed in $15 \%$ formamide $/ 0.2 \times \mathrm{SSC}$ at $42{ }^{\circ} \mathrm{C}$ for $20 \mathrm{~min}, 0.1 \times \mathrm{SSC}$ at $60{ }^{\circ} \mathrm{C}$ for $15 \mathrm{~min}$, and $0.5 \%$ Tween $20 / 4 \times$ SSC at room temperature. The hybridization signals were detected using anti-digoxigenin rhodamine (Roche, Mannheim, Germany).

Oligonucleotides rich in microsatellite sequences $\left[\mathrm{d}(\mathrm{CA})_{15}, \mathrm{~d}(\mathrm{GA})_{15}, \mathrm{~d}(\mathrm{CAA})_{10}\right.$, and $\mathrm{d}(\mathrm{CGG})_{10}$ ] were used as probes as described by [90] and labeled with Alexa-Fluor 555 (Invitrogen, Thermo Fisher Scientific, Waltham, MA, USA) directly during their synthesis (VCB-Biotech). Hybridizations with telomeric sequences (TTAGGG)n were performed using the Telomere PNA FISH/FITC kit (Dako, Glostrup, Denmark) following the manufacturer's instructions. After FISH procedures, the chromosomes were counterstained with Vectashield/DAPI $(1.5 \mu \mathrm{g} / \mathrm{mL})$ anti-fade medium (Vector Laboratories, Burlingame, CA, USA) and analyzed in an epifluorescence microscope Olympus BX51 (Olympus Corporation, Ishikawa, Japan).

Author Contributions: Conceptualization, W.F.M.; data curation, W.F.M.; formal analysis, T.L., W.F.M., and I.M.C.C.; funding acquisition, T.L. and M.B.C.; investigation, T.L., W.F.M., G.W.W.F.C., L.A.C.B., T.E., and M.B.C.; methodology, W.F.M., G.W.W.F.C., and I.M.C.C.; validation, T.L., G.W.W.F.C., L.A.C.B., and M.B.C.; visualization, I.M.C.C., L.A.C.B., and T.E.; writing-original draft, W.F.M.; writing-review and editing, T.L., G.W.W.F.C., I.M.C.C., L.A.C.B., T.E., and M.B.C. All authors have read and agreed to the published version of the manuscript.

Funding: The authors thank the Conselho Nacional de Desenvolvimento Científico e Tecnológico (CNPq) for the financial support (\#442664/2015-0; \#442626/2019-3 and \#301458/2019-7 to W.F.M. and 401962/2016-4; 302449/2018-3 to M.B.C). This study was financed in part by the Coordenação de Aperfeiçoamento de Pessoal de Nivel Superior Brasil (CAPES) - Finance Code 001.

Acknowledgments: The authors thank Water and Sewerage Company of Rio Grande do Norte State (CAERN) by allowing access to Jiqui Lake, where part of the species was collected.

Conflicts of Interest: The authors declare no conflict of interest. The funders had no role in the design of the study; in the collection, analyses, or interpretation of data; in the writing of the manuscript, or in the decision to publish the results.

\section{References}

1. Hassan, H.; Leitão, A.; Al-Shaikh, I.; AL-Maslamani, I. Karyotype of Palaemon khori (Decapoda: Palaemonidae). Vie et Milieu-Life Environ. 2015, 65, 151-155.

2. De Graves, S.; Pentcheff, N.D.; Ahyong, S.T.; Chan, T.Y.; Crandall, K.A.; Dworschak Peter, C.; Felder Darryl, L.; Feldmann Rodney, M.; Fransen Charles, H.J.M.; Goulding Laura, Y.D.; et al. A classification of living and fossil genera of decapod crustaceans. Raffles Bull. Zool. 2009, 21, 1-109.

3. WoRMS Editorial Board. World Register of Marine Species. 2019. Available online: http://www.marinespecies. org (accessed on 19 December 2019). 
4. Holthuis, L.B. FAO species catalogue, Vol. 1. Shrimps and prawns of the world, FAO Fisheries Synopsis No. 125. Food Agric. Organ. United Nations 1980, 1, 271.

5. Jayachandran, K.V. Palaemonid Prawns: Biodiversity, Taxonomy, Biology and Management, 1st ed.; Science Publishers: Enfield, UK, 2001; p. 624.

6. Short, J.W. A revision of Australian river prawns, Macrobrachium (Crustacea: Decapoda: Palaemonidae). Hydrobiologia 2004, 525, 1-100. [CrossRef]

7. Anger, K. Neotropical Macrobrachium (Caridea: Palaemonidae): On the biology, origin, and radiation of freshwater-invading shrimp. J. Crustacean. Biol. 2013, 33, 151-183. [CrossRef]

8. Holthuis, L.B. The Caridean Crustacea of tropical West Africa. Atl. Rep. 1951, 2, 7-187.

9. Melo, G.A.S. Famílias Atyidae, Palaemonidae e Sergestidae. In Manual de Identificação dos Crustacea Decapoda de água doce do Brasil, 1st ed.; Melo, G.A.S., Ed.; Loyola: São Paulo, Brazil, 2003; Volume 1, pp. $289-415$.

10. Ferreira, R.S.; Vieira, R.R.R.; D'Incao, F. The marine and estuarine shrimps of the Palaemoninae (Crustacea: Decapoda: Caridea) from Brazil. Zootaxa 2010, 2606, 1-24. [CrossRef]

11. Rossi, N.; Mantelatto, F.L. Molecular analysis of the freshwater prawn Macrobrachium olfersii (Decapoda, Palaemonidae) supports the existence of a single species throughout its distribution. PloS ONE 2013, 8, e54698. [CrossRef]

12. García-Guerrero, M.U.; Becerril-Morales, F.; Vega-Villasante, F.; Espinosa-Chaurand, L.D. Los langostinos del género Macrobrachium con importancia económica y pesquera en América Latina: Conocimiento actual, rol ecológico y conservación. Lat. Am. J. Aquat. Res. 2013, 41, 651-675. [CrossRef]

13. Chong-Carrillo, O.; Vega-Villasante, F.; Arencibia-Jorge, R.; Akintola, S.L.; Michán-Aguirre, L.; Cupul-Magaña, F.G. Research on the river shrimps of the genus Macrobrachium (Bate, 1868) (Decapoda: Caridea: Palaemonidae) with known or potential economic importance: Strengths and weaknesses shown through scientometrics. Lat. Am. J. Aquat. Res. 2015, 43, 684-690.

14. Damrongphol, P.; Eangchuan, N.; Poolsanguan, B. Spawning cycle and oocyte maturation in laboratorymaintained giant freshwater prawns (Macrobrachium rosenbergii). Aquaculture 1991, 95, 347-357. [CrossRef]

15. Justo, C.C.; Murofushi, M.; Aida, K.; Hanyu, I. Karyological studies on the freshwater prawn Macrobrachium rosenbergii. Aquaculture 1991, 97, 327-334. [CrossRef]

16. Li, Y.; Song, J.; Shen, X.; Cai, Y.; Cheng, H.; Zhang, X.; Yan, B.; Chu, K.H. The first mitochondrial genome of Macrobrachium rosenbergii from China: Phylogeny and gene rearrangement within Caridea. Mitochondrial Dna Part B 2019, 4, 134-136. [CrossRef]

17. Pasookhush, P.; Hindmarch, C.; Sithigorngul, P.; Longyant, S.; Bendena, W.G.; Chaivisuthangkur, P. Transcriptomic analysis of Macrobrachium rosenbergii (giant fresh water prawn) post-larvae in response to M. rosenbergii nodavirus (MrNV) infection: De novo assembly and functional annotation. BMC Genom. 2019, 20, 762. [CrossRef]

18. Kutty, M.N.; Herman, F.; Menn, H.L. Culture of others species. In Freshwater Prawn Farming: The Farming of Macrobrachium rosenbergii, 1st ed.; New, M.B., Valenti, W.C., Eds.; Blackwell Science: Hoboken, NJ, USA, 2000; Volume 1, pp. 393-410.

19. Database on Introductions of Aquatic Species (DIAS). Available online: http://www.fao.org/fishery/dias/en (accessed on 10 January 2020).

20. Barros, M.P.; Silva, L.M.A. Registro de introdução da espécie exótica Macrobrachium rosenbergii (De Man, 1879) (Crustacea, Decapoda, Palaemonidae), em águas do estado do Pará, Brasil. Bol. Mus. Para Emílio. Goeldisér Zool. 1997, 13, 31-37.

21. Cintra, I.H.A.; Silva, K.C.A.; Muniz, A.P.M. Ocorrência de Macrobrachium rosenbergii (De Man, 1879) em áreas estuarinas do Estado do Pará (Crustacea, Decapoda, Palaemonidae). Bol. Técnico. Científico. Cepnor. 2003, 3, 219-227.

22. Iketani, G.; Pimentel, L.; Silva-Oliveira, G.; Maciel, C.; Valenti, W.; Schneider, H.; Sampaio, I. The history of the introduction of the giant river prawn, Macrobrachium cf. rosenbergii (Decapoda, Palaemonidae), in Brazil: New insights from molecular data. Genet. Mol. Biol. 2011, 34, 142-151.

23. Wowor, D.; Muthu, V.; Meier, R.; Balke, M.; Cai, Y.; Ng, P.K.L. Evolution of life history traits in Asian freshwater prawns of the genus Macrobrachium (Crustacea: Decapoda: Palaemonidae) based on multilocus molecular phylogenetic analysis. Mol. Phylogenet. Evol. 2009, 52, 340-350. [CrossRef]

24. Santos, A.; Hayd, L.; Anger, K. A new species of Macrobrachium Spence Bate, 1868 (Decapoda, Palaemonidae), M. pantanalense, from the Pantanal, Brazil. Zootaxa 2013, 3700, 534-546. [CrossRef] 
25. Cai, Y.; Vidthayanon, C. Macrobrachium spelaeus, a new species of stygobitic freshwater prawn from Thailand (Decapoda: Palaemonidae). Raffles B Zool. 2016, 64, 117-122.

26. Zheng, X.-Z.; Chen, W.-J.; Guo, Z.-L. The genus Macrobrachium (Crustacea, Caridea, Palaemonidae) with the description of a new species from the Zaomu Mountain Forest Park, Guangdong Province, China. ZooKeys 2019, 866, 65-83. [CrossRef] [PubMed]

27. Holthuis, L.B. Subfamily Palaemoninae. The Palaemonidae collected by the Siboga and Snellius expeditions with remarks on other species. 1. The Decapoda of the Siboga Expedition Part 10. Siboga Exped. 1950, 39, $1-268$.

28. Holthuis, L.B. The subfamily Palaemoninae. A general revision of the Palaemonidae (Crustacea Decapoda Natantia) of the Americas. 2. Allan Hancock Found. Publ. Occas. Pap. 1952, 12, 39.

29. Liu, M.Y.; Cai, Y.X.; Tzeng, C.S. Molecular systematics of the freshwater prawn genus Macrobrachium Bate, 1868 (Crustacea: Decapoda: Palaemonidae) inferred from mtDNA sequences, with emphasis on East Asian species. Zool. Stud. 2007, 46, 272-289.

30. Pileggi, L.G.; Mantelatto, F.L. Taxonomic revision of doubtful Brazilian freshwater shrimp species of genus Macrobrachium (Decapoda, Palaemonidae). Iheringia. Sér. Zool. 2013, 102, 426-437. [CrossRef]

31. González-Tizón, A.M.; Rojo, V.; Menini, E.; Torrecilla, Z.; Martínez-Lage, A. Karyological analysis of the shrimp Palaemon serratus (Decapoda: Palaemonidae). J. Crustacean. Biol. 2013, 33, 843-848. [CrossRef]

32. Phimphan, S.; Tanomtong, A.; Seangphan, N.; Sangpakdee, W. Chromosome studies on freshwater prawn, Macrobrachium lanchesteri (Decapoda, Palaemonidae) from Thailand. Nucleus 2019, 62, 77-82. [CrossRef]

33. Lee, T.H.; Naitoh, N.; Yamazaki, F. Chromosome studies on the mitten crabs Eriocheir japonica and E. sinensis. Fish. Sci. 2004, 70, 211-214. [CrossRef]

34. Choudhary, N.; Sharma, R.; Asthana, S.; Vyas, P.; Rather, M.A.; Reddy, A.K.; Krishna, G. Development of karyotype and localization of cytogenetic markers in Dimua River prawn, Macrobrachium villosimanus (Tiwari, 1949). J. Biol. Sci. 2013, 13, 507-513.

35. Vishnoi, D.N. Studies on the chromosomes of some Indian Crustacea. Cytologia 1972, 37, 43-51. [CrossRef]

36. Qiu, G.; Du, N.; Lai, W. Chromosomal and karyological studies on the freshwater prawn Macrobrachium nipponense (Crustacea, Decapoda). Oceanol. Limnol. Sin. 1994, 25, 493-498.

37. Lakra, W.S.; Kumar, P. Studies on the chromosomes of two freshwater prawns, Macrobrachium idella and M. scabriculum (Crustacea, Decapoda, Palaemonidae). Cytobios 1995, 84, 147-156.

38. Mittal, O.P.; Dhall, U. Chromosome studies in three species of freshwater decapods (Crustacea). Cytologia 1971, 36, 633-638. [CrossRef]

39. Gaofeng, Q. Studies on chromosomes of Macrobrachium superbum Heller (Crustacea, Decapoda). J. Fish. Sci. China 1997, 1997, 1.

40. Jiang, Y.; Xie, S.; Zhou, Q.; Lan, W. Chromosome karyotype in freshwater prawn Exopalaemon modestus. Fish. Sci. 2008, 9, 013.

41. Torrecilla, Z.; Martínez-Lage, A.; Perina, A.; González-Ortegón, E.; González-Tizón, A.M. Comparative cytogenetic analysis of marine Palaemon species reveals a X1X1X2X2/X1X2Y sex chromosome system in Palaemon elegans. Front. Zool. 2017, 14, 47. [CrossRef] [PubMed]

42. Lakra, W.S.; Kumar, P.; Das, M.; Goswami, U.M. Improved techniques of chromosome preparation from shrimp and prawns. Asian Fish. Sci. 1997, 10, 117-121.

43. Trentini, M.; Corni, M.G.; Froglia, C. The chromosomes of Liocarcinus vernalis (Risso, 1816) and Liocarcinus depurator (L.; 1758) (Decapoda, Brachyura, Portunidae). Biol. Zent. Bl. 1989, 108, 163-166.

44. Niiyama, H. A comparative study of the chromosomes in decapods, isopods and amphipods, with some remarks on cytotaxonomy and sex determination in the Crustacea. Fac. Fish. Sci. Hokkaido Univ. 1959, 7, 1-60.

45. Lécher, P.; Defaye, D.; Noel, P. Chromosomes and nuclear DNA of Crustacea. Invertebr. Reprod. Dev. 1995, 27, 85-114. [CrossRef]

46. Lester, L.J. Population genetics of penaeid shrimp from the Gulf of Mexico. J. Hered. 1979, 70, $175-180$. [CrossRef]

47. Benzie, J.A.H. Population genetic structure in penaeid prawns. Aquac. Res. 2000, 31, 95-119. [CrossRef]

48. Campos-Ramos, R. Chromosome studies on the marine shrimps Penaeus vannamei and P. californiensis (Decapoda). J. Crustacean. Biol. 1997, 17, 666-673. [CrossRef] 
49. Zhang, X.; Zhou, L.; Xiang, J. Studies on the chromosome of marine shrimps with special reference to different techniques. In Proceedings of the Abstracts of Plant, Animal and Microbe Genomes X Conference, San Diego, CA, USA, 12-16 January 2002; p. 642.

50. Chen, P.-C.; Shih, C.-H.; Chu, T.-J.; Lee, Y.-C.; Tzeng, T.-D. Phylogeography and genetic structure of the oriental river prawn Macrobrachium nipponense (Crustacea: Decapoda: Palaemonidae) in East Asia. PLoS ONE 2017, 12, e0173490. [CrossRef]

51. Lingyun, Y.; Xinping, Z.; Jianhui, L.; Jiajia, F.; Chen, C. Analysis of genetic structure of wild and cultured giant freshwater prawn (Macrobrachium rosenbergii) using newly developed microsatellite. Front. Mar. Sci. 2019, 6, 323.

52. Motta-Neto, C.C.; Cioffi, M.B.; Costa, G.W.W.F.; Amorim, K.D.J.; Bertollo, L.A.C.; Artoni, R.F.; Molina, W.F. Overview on karyotype stasis in Atlantic grunts (Eupercaria, Haemulidae) and the evolutionary extensions for other marine fish groups. Front. Mar. Sci. 2019, 6, 628. [CrossRef]

53. Vera-Silva, A.L.; Carvalho, F.L.; Mantelatto, F.L. Distribution and genetic differentiation of Macrobrachium jelskii (Miers, 1877) (Natantia: Palaemonidae) in Brazil reveal evidence of non-natural introduction and cryptic allopatric speciation. J. Crustacean. Biol. 2016, 36, 373-383. [CrossRef]

54. Chen, R.-T.; Tsai, C.; Tzeng, W.-N. Freshwater prawns (Macrobrachium Bate, 1868) of Taiwan with special references to their biogeographical origins and dispersion routes. J. Crustacean. Biol. 2009, 29, 232-244. [CrossRef]

55. Jose, D.; Harikrishnan, M. Evolutionary history of genus Macrobrachium inferred from mitochondrial markers: A molecular clock approach. Mitochondrial Dna Part A 2018, 30, 92-100. [CrossRef]

56. Sochorová, J.; Garcia, S.; Gálvez, F.; Symonová, R.; Kovařík, A. Evolutionary trends in animal ribosomal DNA loci: Introduction to a new online database. Chromosoma 2018, 127, 141-150. [CrossRef]

57. Summer, A.T. Banding with nucleases. In Chromosome banding, 1st ed.; Summer, A.T., Ed.; Springer: Boston, MA, USA, 1990; Volume 1, pp. 253-271.

58. Coluccia, E.; Deiana, A.M.; Cannas, R.; Salvadori, S. Study of the nucleolar organizer regions in Palinurus elephas (Crustacea: Decapoda). Hydrobiologia 2006, 557, 5-8. [CrossRef]

59. Salvadori, S.; Coluccia, E.; Deidda, F.; Cau, A.; Cannas, R.; Deiana, A.M. Comparative cytogenetics in four species of Palinuridae: B chromosomes, ribosomal genes and telomeric sequences. Genetica 2012, 140, 429-437. [CrossRef] [PubMed]

60. Mais, C.; Wright, J.E.; Prieto, J.L.; Raggett, S.L.; McStay, B. UBF-binding site arrays form pseudo-NORs and sequester the RNA polymerase I transcription machinery. Genes. Dev. 2004, 1, 50-64. [CrossRef] [PubMed]

61. Prieto, J.L.; McStay, B. Pseudo-NORs: A novel model for studying nucleoli. Biochim. Biophys. Acta 2008, 1783, 2116-2123. [CrossRef] [PubMed]

62. Mlinarec, J.; Mczic, M.; Pavlica, M.; Srut, M.; Klobucar, G.; Maguire, I. Comparative karyotype investigations in the European crayfish Astacus astacus and A. leptodactylus (Decapoda, Astacidae). Crustaceana 2011, 84, 1497-1510.

63. Blackburn, E.H. Structure and function of telomeres. Nature 1991, 350, 569-573. [CrossRef] [PubMed]

64. Meyne, J.; Ratliff, L.R.; Moyzis, R.K. Conservation ofthe human telomere sequence (TTAGGG) among vertebrates. PNAS 1989, 86, 7049-7053. [CrossRef]

65. Pelliccia, F.; Volpi, E.V.; Lanza, V.; Gaddini, L.; Baldini, A.; Rocchi, A. Telomeric sequences of Asellus aquaticus (Crust. Isop.). Heredity 1994, 72, 78-80. [CrossRef]

66. Salvadori, S.; Deidda, F.; Cau, A.; Sabatini, A.; Cannas, R.; Deiana, A.M.; Lobina, C. Karyotype, ribosomal genes, and telomeric sequences in the crayfish Procambarus clarkii (Decapoda: Cambaridae). J. Crustacean. Biol. 2014, 34, 525-531. [CrossRef]

67. Ritchie, H.; Jamieson, A.J.; Piertney, S.B. Genome size variation in deep-sea amphipods. Roy. Soc. Open Sci. 2017, 4, 170862. [CrossRef]

68. Yuan, J.; Gao, Y.; Zhang, X.; Wei, J.; Liu, C.; Li, F.; Xiang, J. Genome sequences of marine shrimp Exopalaemon carinicauda Holthuis Provide insights into genome size evolution of Caridea. Mar. Drugs 2017, 15, 213. [CrossRef] [PubMed]

69. Zhao, C.; Zhang, X.; Liu, C.; Huan, P.; Li, F.; Xiang, J.; Huang, C. BAC end sequencing of Pacific white shrimp Litopenaeus vannamei: A glimpse into the genome of Penaeid shrimp. Chin. J. Oceanol. Limn. 2012, 30, 456-470. [CrossRef] 
70. Ahmed, M.; Liang, P. Transposable elements are a significant contributor to tandem repeats in the human genome. Int. J. Genom. 2012, 2012, 947089. [CrossRef]

71. Schemberger, M.O.; Nascimento, V.D.; Coan, R.L.; Ramos, É.L.; Nogaroto, V.; Ziemniczak, K.; Valente, G.T.; Moreira-Filho, O.; Martins, C.; Vicari, M.R. DNA transposon invasion and microsatellite accumulation guide W chromosome differentiation in a Neotropical fish genome. Chromosoma 2019, 128, 547-560. [CrossRef]

72. Abbott, R.; Albach, D.; Ansell, S.; Arntzen, J.W.; Baird, S.J.E.; Bierne, N.; Boughman, J.; Brelsford, A.; Buerkle, C.A.; Buggs, R.; et al. Hybridization and speciation. J. Evol. Biol. 2013, 26, 229-246. [CrossRef]

73. Mallet, J.; Besansky, N.; Hahn, M. How reticulated are species? BioEssays 2016, 38, 140-149. [CrossRef]

74. Shokita, S. Larval development of interspecific hybrid between Macrobrachium asperulum from Taiwan and Macrobrachium shokitai from the Ryukyus. Bull. Jap. Soc. Sci. Fish. 1978, 44, 1187-1195. [CrossRef]

75. Sankolli, K.; Shenoy, S.; Jalihal, D.; Almelkar, G. Crossbreeding of the giant freshwater prawns Macrobrachium rosenbergii (De Man) and M. malcolmsonii (H. Milne Edwards). In Giant Prawn Farming, 1st ed.; New, M.B., Ed.; Elsevier: Amsterdam, The Netherlands, 1982; Volume 1, pp. 91-98.

76. Soundarapandian, P.; Kannupandi, T. Larval production by crossbreeding and artificial insemination of freshwater prawns. Indian J. Fish. 2000, 47, 97-101.

77. Fu, H.; Gong, Y.; Wu, Y.; Xu, P.; Wu, C. Artificial interspecific hybridization between Macrobrachium species. Aquaculture 2004, 232, 215-223. [CrossRef]

78. Graziani, C.; Moreno, C.; Villarroel, E.; Orta, T.; Lodeiros, C.; De Donato, M. Hybridization between the freshwater prawns Macrobrachium rosenbergii (De Man) and M. carcinus (L). Aquaculture 2003, 217, 81-91. [CrossRef]

79. Misamore, M.; Browdy, C.L. Evaluating hybridization potential between Penaeus setiferus and P. vannamei through natural mating, artificial insemination and in vitro fertilization. Aquaculture 1997, 150, 1-10. [CrossRef]

80. Arnold, M.L. Natural Hybridization and Evolution, 1st ed.; Oxford University Press: Oxford, UK, 1997; p. 228.

81. Chapman, M.A.; Burke, J.M. Genetic divergence and hybrid speciation. Evolution 2007, 61, $1773-1780$. [CrossRef] [PubMed]

82. Dobkin, S.A.; Azzinaro, W.P.; Montfrans Van, J. Culture of Macrobrachium acanthurus and M. carcinus with notes on the selective breeding and hybridization of these shrimps. Proc. Annu. Meeting. World Maric. Soc. 1974, 5, 51-62. [CrossRef]

83. Sandifer, P.A.; Smith, T.I.J. A method for artificial insemination of Macrobrachium prawns and its potential use in inheritance and hybridization studies. Proc. World Maric. Soc. 1979, 10, 403-418. [CrossRef]

84. Savaya-Alkalay, A.; Ndao, P.D.; Jouanard, N.; Diane, N.; Aflalo, E.D.; Barki, A.; Sagi, A. Exploitation of reproductive barriers between Macrobrachium species for responsible aquaculture and biocontrol of schistosomiasis in West Africa. Aquac. Environ. Interact. 2018, 10, 487-499. [CrossRef]

85. Klingerman, A.D.; Bloom, S.E. Rapid chromosome preparation from solid tissue of fishes. J. Fish. Res. Board. Can. 1977, 34, 266-269. [CrossRef]

86. Levan, A.; Fredga, K.; Sandberg, A. Nomenclature for centromeric position on chromosomes. Hereditas 1964, 52, 201-220. [CrossRef]

87. Howell, W.M.; Black, D.A. Controlled silver-staining of nucleolus organizer regions with a protective colloidal developer a 1-step method. Experientia 1980, 36, 1014-1015. [CrossRef]

88. White, T.J.; Bruns, T.; Lee, S.; Taylor, J. Amplification and direct sequencing of fungal ribosomal RNA genes for phylogenetics. In PCR Protocols: A Guide to Methods and Applications, 1st ed.; Innis, M., Gelfand, D., Sninsky, J., White, T., Eds.; Academic Press Inc.: Orlando, FL, USA, 1989; Volume 1, pp. 315-322.

89. Pinkel, D.; Straume, T.; Gray, J.W. Cytogenetic analysis using quantitative, high-sensitivity, fluorescence hybridization. PNAS 1986, 83, 2934-2938. [CrossRef]

90. Kubat, Z.; Hobza, R.; Vyskot, B.; Kejnovsky, E. Microsatellite accumulation on the Y chromosome in Silene latifolia. Genome 2008, 51, 350-356. [CrossRef]

(C) 2020 by the authors. Licensee MDPI, Basel, Switzerland. This article is an open access article distributed under the terms and conditions of the Creative Commons Attribution (CC BY) license (http://creativecommons.org/licenses/by/4.0/). 